\title{
A landform evolution model for the Mannen area in Romsdal valley, Norway
}

\author{
Paula Hilger ${ }^{(1)}$, Reginald L. Hermanns ${ }^{(2)}$, Bernd Etzelmüller ${ }^{(3)}$
}

2020 Kyoto Japan

\begin{abstract}
The Quaternary geology of western Norway's landscape is the result of glacial and post-glacial sedimentation and erosional processes, a significant sea-level drop and high rock-slope failure activity. All these processes are represented within a small valley section below the Mannen rock-slope instability in Romsdal valley, western Norway. Here, exposure ages, Quaternary geological mapping and geophysical investigations permit the development of a paraglacial landscape evolution model. The model contextualises at least six catastrophic rock-slope failure events within the overall sequence of fjord-valley infilling following deglaciation. A transition from a wide, basin-like valley into a strongly confined valley section led to the build-up of more than $40 \mathrm{~m}$ thick stratified drift, which was at least partly deposited within a marine environment. The morphology of these sediments features two distinct erosional levels, which are interpreted to be connected to tidal currents during post-glacial sea-level drop. The landform evolution model illustrates the importance of catastrophic rock-slope failures and the impact of strong tidal currents on the typical sediment fill in narrow, high-relief fjord valleys.
\end{abstract}

\section{Keywords}

Fjord-valley fill, catastrophic rock-slope failures, ${ }^{10}$ Be dating, Quaternary geology, paraglacial landscape evolution

\section{Introduction}

The unique landscape of Norway, with its deep fjords and valleys is the result of several glaciations, interglacial isostatic rebound and connected sedimentation and erosion processes. The oversteepened slopes along the valleys are characterised by a high mass-wasting activity, including rock fall, rock sliding and rock avalanches. These processes add significantly to the paraglacial landscape evolution within the valleys. The importance of large rock-slope failures on landscape responses has been shown on examples in the Himalaya, the Tien-Shan, the European Alps and the Southern Alps in New Zealand (Korup et al., 2006, Korup and Schlunegger, 2007, Larsen et al., 2010). However, well accepted evolution models of Norwegian fjord-valley fill, do often not account for the impact and evolutional effect of large catastrophic rock-slope failures (e.g. Corner, 2006; Eilertsen et al., 2006).

This conference paper is an extension to a previously published study by Hilger et al. (2018). The aim is to present a landform evolution model of an area in a glacially eroded valley that has been subjected to both glacial and deglacial sedimentation processes, significant sea-level fall and colluvial and rock-slope failure activity within a time period a few thousand years. We present an interpretation of previously mapped Quaternary stratigraphy and Holocene landforms, contextualising local rock-slope failure activity within the framework of a fjord-valley fill succession. This novel model may be relevant for many fjord-valley settings in Norway.

\section{Setting}

Romsdal valley is a glacially formed, sediment-filled palaeofjord. The valley cuts through the Western Gneiss Region and is characterised by a high rock-slope failure activity due to inherent critical weaknesses along the oversteepened rock slopes (Blikra et al., 2006; Saintot et al., 2012). In the lower reach of the valley the slopes are between 800 and $1400 \mathrm{~m}$ high and have an average gradient of $>45^{\circ}$ (Fig. 1 ).

The area of interest of this paper is a valley section below the rock-slope instability of Mannen, where the valley width decreases significantly. A basin-like low-gradient section is followed by a strongly confined cross section and a knickpoint in the longitudinal profile (Figs. 1 and 2). 


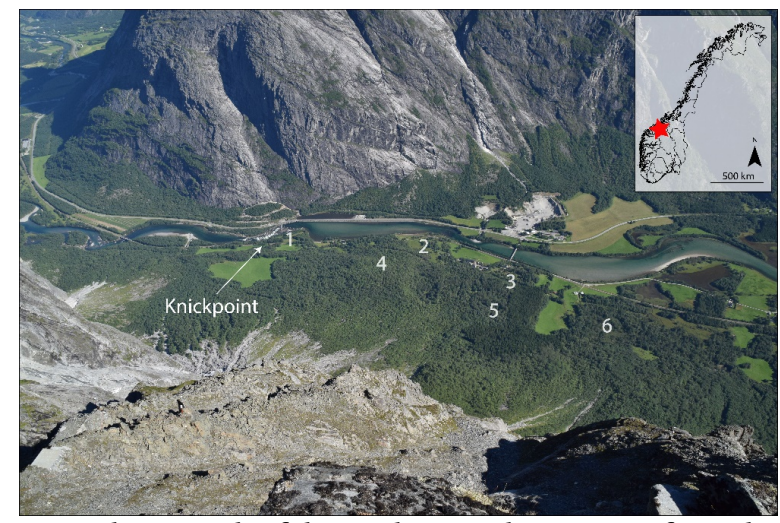

Fig. 1 Photograph of the study site taken in 2016 from the top of the Mannen rock-slope instability. The photo features the transition from a wide cross section to a strongly confined valley section. A knickpoint in the river's long profile, visible due to rapids, is created by a rock-slope failure event. Numbers 1-6 represent rockslope failure deposits hidden under the forest.

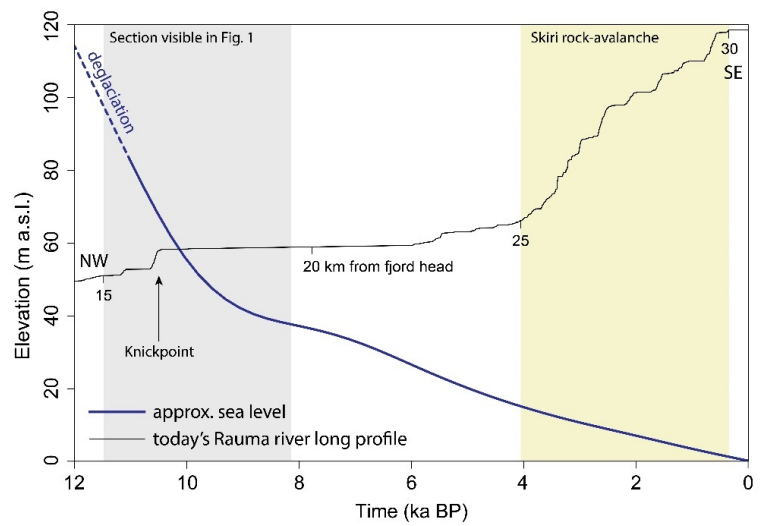

Fig. 2 Sea-level curve approximated after Svendsen \& Mangerud (1987) and long profile of today's Rauma river. Numbers along the river profile represent the distance to the fjord head in kilometres. The area of interest of this paper lies between $\mathrm{km} 15$ and 19 and is marked in grey. In the upper reach, deposits of the Skiri rock avalanche form a dam and thus a significant knickpoint in the river profile (yellow section).

During late deglaciation (ca. 13-11.7 ka; Hermanns et al., 2017, Hughes et al., 2016, Stroeven et al., 2016) this part of the Romsdal valley was inundated by seawater, reaching a marine limit of $120 \mathrm{~m}$ above modern sea level (Høgaas et al., 2012). Sediments covering the valley floor are thus the product of processes connected to the Pleistocene glaciation, post-glacial sea-level fall and paraglacial slope processes.

\section{Brief summary of methods}

\section{Quaternary geological mapping}

We combined GIS-based mapping and relief analyses using high-resolution digital elevation models (DEM) and aerial photographs with field work. This allowed us to map and interpret the stratigraphy in the context of the valleys' morphology. Quaternary geological mapping included geophysical surveys using Electrical Resistivity Tomography (ERT) and Ground Penetrating Radar (GPR) in order to derive the stratigraphical sequences of defined sedimentary facies (Hilger et al., 2018).

\section{Geochronology}

In order to establish apparent exposure ages of prehistorical rock-slope failures at Mannen, Hilger et al. (2018) analysed samples from 13 rockslide boulders for cosmogenic ${ }^{10} \mathrm{Be}$. The sampled boulders represent at least four catastrophic rock-slope failure events with two to five samples per deposit. Except for the deposits of rock avalanche $\mathrm{N}_{2}{ }_{2}$ (Figs. 1 and 3 ) the samples are well distributed (cf. Hilger et al., 2018).

Due to expected old ages and the likeliness of failure into water, samples for ${ }^{10} \mathrm{Be}$ dating were neither collected from the lower part of event $\mathrm{N}^{\circ} 2$ nor from the deposits of events $\mathrm{N}^{\circ} 1$ and 3 . The failure timing of these three events was obtained through relative correlation of the mapped stratigraphy and erosional features.

\section{Summary of results}

\section{Quaternary geology}

One of the main results of the mapping is a simplified Quaternary geological map of the study site (Fig. 3). Hilger et al. (2018) present three composite sediment profiles from the local stratigraphy featuring the following sedimentary facies: stratified drift (FA I; sand and gravel with blocks and boulders), distal fluvial/debris flow deposits from the slopes (FA II; mostly sand), catastrophic rock-slope failure deposits (FA III; gravel with chaotic boulder fields on top) and a small section of overbank fluvial deposits (FA IV; silt and fine sand). The central part of the valley, closest to the Rauma river, is characterised by recent fluvial sediments. The superficial deposits are dominated by large talus slopes and several deposits from catastrophic rock-slope failures reaching beyond the foot of the colluvium.

The sands and gravels of the stratified drift dips c. $5^{\circ}$ into downstream direction and form two rather flat $\left(<5^{\circ}\right)$ elevated surfaces c. 40 and $20 \mathrm{~m}$ above today's river level, respectively. The surfaces are 10-20 $\mathrm{m}$ higher than any glacio-fluvial or fluvial terrace mapped along Romsdal valley (Hilger et al., 2018). These surfaces relate to two well-defined topographical steps with a distinct 


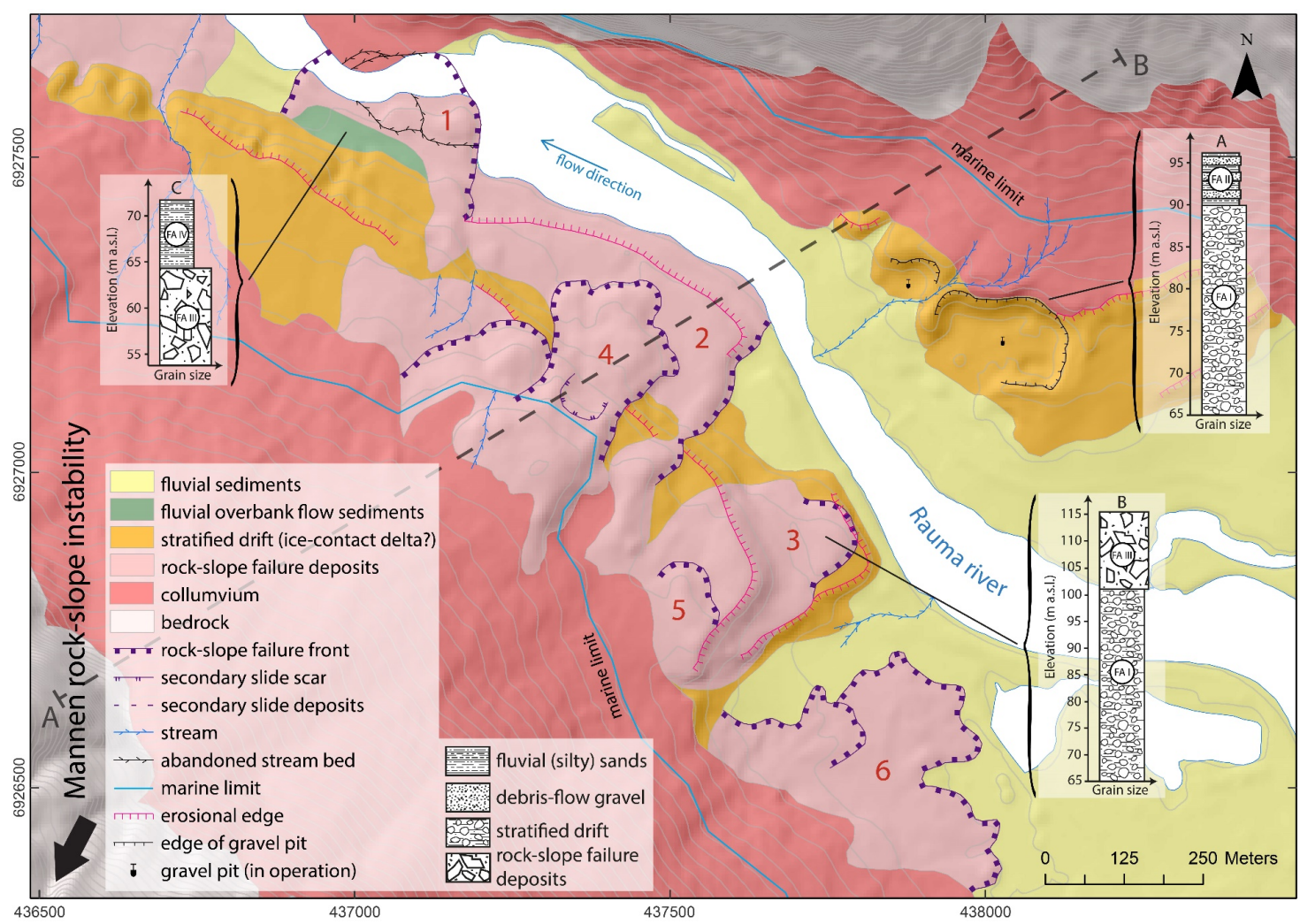

Fig. 3: Quaternary geological map of the Romsdal valley section below the Mannen rock-slope instability. Deposits from catastrophic rock-slope failure events are numbered from 1 to 6 for easier referencing. The stratigraphy for three locations is included. The dashed gray line indicates the approximate location of profile A-B in Fig. 4 (adapted from Hilger et al., 2018).

transition from $35^{\circ}$ steep erosional slopes to the flat surfaces (Fig. 3). There is an almost abrupt transition from a cross-valley direction into a valley parallel direction of these topographical steps (Fig. 3).

\section{Age constraints}

${ }^{10}$ Be-dating results suggest that $\sim 5000$ years ago three to six catastrophic rock-slope failures took place within a few hundred years $\left(\mathrm{N}^{\circ}{ }_{4}-6\right.$, Tab. 1, Hilger et al., 2018). Based on the error weighted mean of two samples, an additional event ( $\mathrm{N}^{\circ}$, Fig. 3 ) has an apparent exposure age of $9.39 \pm 0.64 \mathrm{ka}$. The geomorphological appearance of the deposit however suggests that the real failure timing lies within the upper range of this result, or beyond. The lower part of this deposit shows clear erosional signs up to $20 \mathrm{~m}$ above todays river level, which indicates failure into a higher water level and thus earlier than 10 ka (Fig. 2). This is also true for deposits $\mathrm{N}^{\circ} 1$ and 3 , where the erosional edge of the stratified drift runs very distinctly through the deposits (Fig. 3).
Table 1 Age constraints for a minimum of six catastrophic rock-slope failure events from Mannen.

\begin{tabular}{|l|l|l|}
\hline $\begin{array}{c}\text { CRSF } \\
\left(\mathrm{N}^{\circ}\right)\end{array}$ & \multicolumn{1}{|c|}{$\begin{array}{c}\text { Appr. failure timing } \\
(\mathrm{ka}( \pm 1 \sigma))\end{array}$} & \multicolumn{1}{c|}{ Method } \\
\hline 1 & $10.5-12$ & Stratigraphy \\
\hline 2 & $9-12$ & $\begin{array}{l}{ }^{10} \mathrm{Be}(2 \text { samples })+ \\
\text { stratigraphy }\end{array}$ \\
\hline 3 & $10-12$ & Stratigraphy \\
\hline 4 & $4.93 \pm 0.31$ & ${ }^{10} \mathrm{Be}(5$ samples $)$ \\
\hline 5 & $4.96 \pm 0.33$ & ${ }^{10} \mathrm{Be}(2$ samples $)$ \\
\hline 6 & $4.95 \pm 0.31$ & ${ }^{10} \mathrm{Be}(3$ samples $)$ \\
\hline
\end{tabular}

\section{A landform evolution model}

Our Quaternary geological and geomorphological observations invite to reconstruct the landscape development in such a typical but also specific fjordvalley setting. 


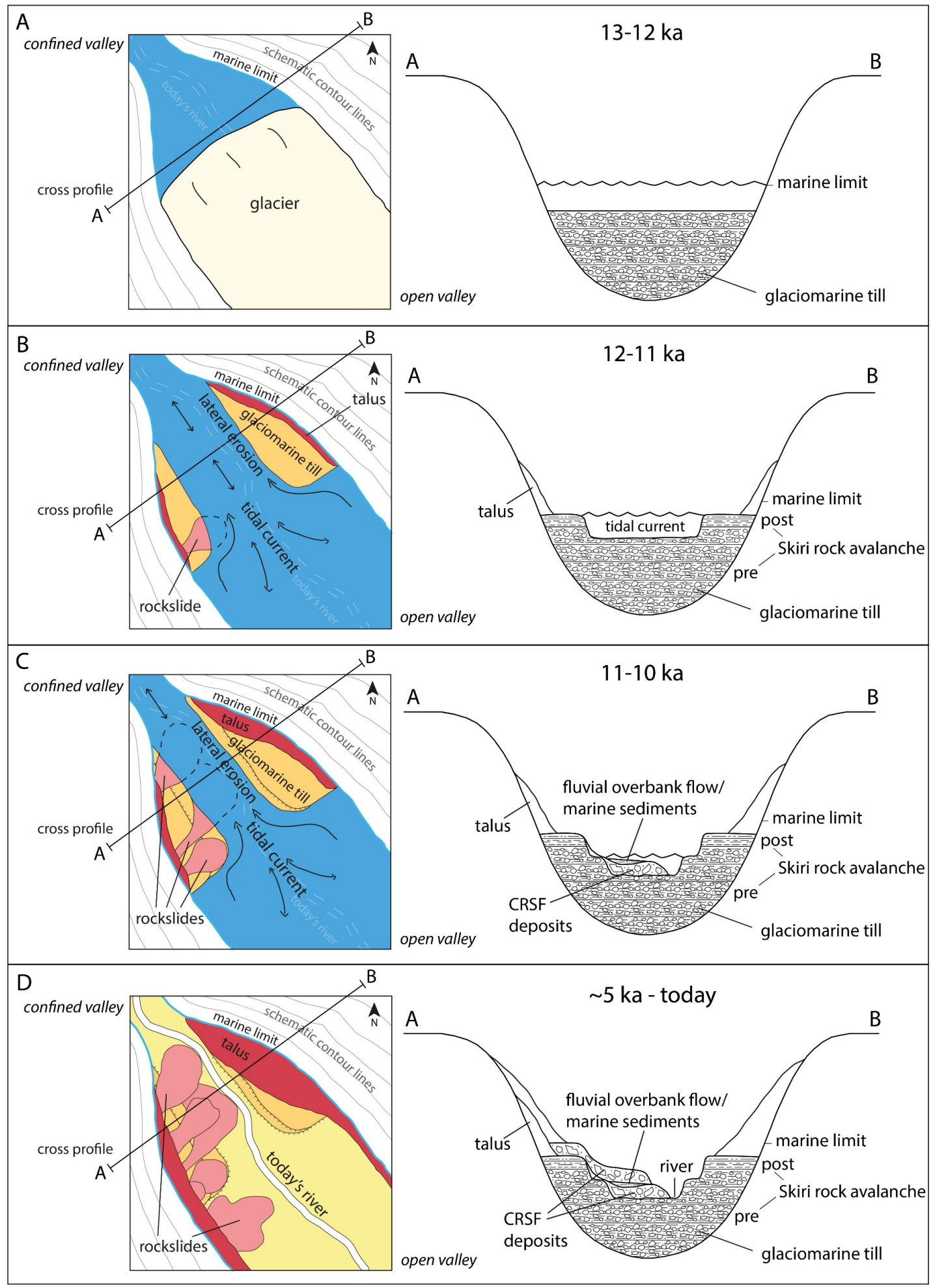

Fig. 4 Schematic illustration of a Holocene landscape evolution model for the section of the Romsdal valley below Mannen. The section is characterised by an increasing valley confinement which enhanced currents during tidal reversals while the sea level was dropping. The cross-section A-B indicates the sedimentology with depth for each time step. Catastrophic rock-slope failures are abbreviated with CRSF. 
The Quaternary geology in this type of valleys is dominated by glacial and marine sediments modified by a high mass-wasting activity and fluvial erosion and deposition.

The several tens of meter thick stratified gravels and sands below Mannen are considered to be older than the failure timing of a large rock-avalanche in the upper reach of Romsdal valley (10.5-11.7 ka; Hermanns et al., 2017) and underlie deposit $\mathrm{N}_{3}^{\circ}$ (Fig. 3). The rock masses of the Skiri rock avalanche (Fig. 2) dammed the river and must have retained at least large parts of the later, coarse glacio-fluvial sediments. The dam was never eroded and still represents a barrier of the Rauma valley (Hermanns et al., 2013). Based on the failure timing of the Skiri rockavalanche, the stratified drift was deposited in a marine environment (Fig. 4A). Deposition processes could have been similar to those of a submarine fan or ice-contact underwater fan (Lønne, 1995; Winsemann et al., 2009). This is supported by the abrupt appearance of the glacial drift within the basin-like valley opening, with a steep slope running orthogonally to the valley (Fig. 3).

The confined valley section on the downstream side probably led to a quick build-up of 20-30 m thick layers of glacio-marine till with a sharp ice-contact line valley upwards. While fine sediments were evacuated, coarser till deposits persisted behind the chokepoint. An observed sharp transition from glacio-marine till to finegrained sediments on top could be an indicator for the timing of the Skiri rock-avalanche, retaining the coarse grain size fraction (Fig. $4 \mathrm{~B}$ ). The top surface of these sediments reaches an elevation of $90 \mathrm{~m}$ a.s.l. in the north-west to $100 \mathrm{~m}$ a.s.l. in the south-east. These elevations coincide with the sea level between 11 and $12 \mathrm{ka}$, when wave and tidal activity must have produced flat erosional surfaces and steep longitudinal erosional edges (Fig. 4 B). The $\sim 5^{\circ}$ inclination of the upper elevated surface indicates the formation at an early stage of isostatic rebound, when the sea level was still high. It is likely that velocities of the currents, connected to the tide reversals were increased by the strong convergence in valley width in this section (Ross et al., 2017) and led to incision and strong lateral erosion in the central part. The deposits of three early (12-10 ka) catastrophic rockslope failures reached, at least partly, into the fjord environment (Fig. 4 C). Erosional modification of the deposits can be connected to the continued strong tidal activity and valley-parallel currents during the ongoing rapid sea-level drop. The height of the erosional edges suggests that tidal currents have been effective from deglaciation to about $10 \mathrm{ka}$ when the sea level dropped to the recent river level (Figs. 3 and 4 D).

\section{Discussion and conclusion}

The presented model is plausible and demonstrates the erosional force tidal currents can have in such settings. Interesting within this context are the two distinct surface levels, which may be connected to changes in the velocity of isostatic rebound, and thus the elevation of the shoreline.

The valley section below the Mannen instability in Romsdal valley stands out from the typical fjord-valley stratigraphy and morphology (cf. Corner, 2006). This is caused by a short transition from a wide $\mathrm{u}$-shaped cross section to a confined valley section and a high activity of catastrophic rock-slope failures. On one hand, the valley constriction acted as chokepoint and led to a quick build-up of thick stratified drift, likely deposited as glaciomarine contact-fan or -delta. On the other hand, it intensified tidal currents during post-glacial sea-level drop (cf. Ross et al., 2017), increasing lateral erosion and forming two $20 \mathrm{~m}$ high steps above today's riverbanks. Because of the particular topography in an otherwise typical fjord-valley setting, we expect similar features in several valleys with alike topographical chokepoints, sustaining our model.

This study shows the significance of catastrophic rockslope failures on landscape development in valleys. The Skiri rock avalanche has dammed the Rauma river and thus retained coarse glaciofluvial sediments. More than 10,00o years later, the deposits still form a significant knickpoint in the valley's long profile (Fig. 2). The effect of the landslide dam is thus overruling forcing factors for river adjustment (e.g. Korup et al., 2006, Ouimet et al., 2007).

Another minor but distinct knickpoint was formed at a similar time in the area of interest of this study. Here, catastrophic rock-slope failures, reaching far beyond large talus slopes along the valley sides, are significant components of the paraglacial landscape development and the Quaternary geology of this valley section. The deposits of three large rock-slope failures are affected by the early tidal erosion, and a failure timing before $10 \mathrm{ka}$ is suggested by stratigraphic relations. Three distinct deposits, which represent up to six rock-slope failure events are dated to $5 \mathrm{ka}$ ago. The deposits are well preserved and will most likely survive and dominate the landscape for thousands of years to come.

\section{Acknowledgments}

This study is part of the project 'CryoWALL - Permafrost slopes in Norway' (243784/CLE) funded by the Research Council of Norway (RCN).

We thank our project partners and co-authors from Hilger et al. (2018) Benjamin Jacobs, Michael Krautblatter and John C. Gosse for their cooperation and 
support. Sample processing for ${ }^{10} \mathrm{Be}$ dating was conducted by the first author at Cosmic Ray Isotope Sciences at Dalhousie University (CRISDal) with great help of John C. Gosse and G. Yang.

\section{References}

Blikra LH, Longva O, Braathen A, Anda E, Dehls JF, Stalsberg $K$ (2006) Rock slope failures in Norwegian fjord areas: Examples, spatial distribution and temporal pattern. In: Evans SG, Mugnozza GS, Strom A, Hermanns RL (eds). Landslides from Massive Rock Slope Failure (NATO Science Series, vol. 49). Springer, Dodrecht. pp. 475-496.

Corner GD (2006) A transgressive-regressive model of FjordValley fill: Stratigraphy, facies and depositional controls. In: Dalrymple RW, Leckie DA and Tillman RW (eds). Incised Valleys in Time and Space. SEPM Society for Sedimentary Geology (Special Publication no. 85, ISBN10: 1565761227) pp. 161-178.

Eilertsen RS, Corner GD, Aasheim O, Andreassen K, Kristofferson Y, Ystborg $\mathrm{H}$ (2006) Valley-fill stratigraphy and evolution of the Malselv Fjord Valley, Northern Norway. In: Dalrymple RW, Leckie DA and Tillman RW (eds). Incised Valleys in Time and Space. SEPM Society for Sedimentary Geology (Special Publication no. 85, ISBN10: 1565761227) pp. 179-195.

Hermanns RL, Dahle H, Bjerke PL, Crosta GB, Anda E, Blikra LH, Saintot A, Longva O (2017) Rockslide Dams in Møre og Romsdal County, Norway. In: Margottini C, Canuti P, Sassa K (eds). Landslide Science and Practice - Volume 6: Risk Assessment, Management and Mitigation. Springer, Berlin, Heidelberg. (ISBN: 978-3-642-31319-6) pp. 3-12.

Hermanns RL, Schleier M, Bohme M, Blikra LH, Gosse JC, IvyOchs S, Hilger P (2017) Rock-avalanche activity in W and $S$ Norway peaks after the retreat of the Scandinavian Ice Sheet. In: Mikoš M, Vilimek V, Yin Y, Sassa K (eds). Advancing Culture of Living with Landslides. Springer, Cham. pp. 331-338.

Hilger P, Hermanns RL, Gosse JC, Jacobs B, Etzelmüller B, Krautblatter M (2018) Multiple rock-slope failures at Mannen in Romsdal Valley, western Norway, revealed from Quaternary geological mapping and ${ }^{10} \mathrm{Be}$ exposure dating. The Holocene. 28(12): 1841-1854.

Hughes ALC, Gyllencreutz R, Lohne OS, Mangerud J, Svendsen JI (2016) The last Eurasian ice sheets - A chronological database and time-slice reconstruction, DATED-1. Boreas 45: 1-45.

Høgaas F, Hansen L, Rinstad BI, Sveian H, Olsen L (2012). Database for registrering av marin grense (MG) i Norge. NGU-report 2012.063, Geological Survey of Norway, Trondheim. (ISSN: 0800-3416).

Lønne I (1995) Sedimentary facies and depositional architecture of ice-contact glaciomarine systems. Sedimentary Geology. 98(1-4): 13-43.

Korup O, Strom AL, Weidinger JT (2006) Fluvial response to large rock-slope failures: Examples from the Himalayas, the Tien Shan, and the Southern Alps in New Zealand. Geomorphology. 78(1-2): 3-21.

Korup O, Schlunegger F (2007) Bedrock landsliding, river incision, and transience of geomorphic hillslope-channel coupling: Evidence from inner gorges in the Swiss Alps. Journal of Geophysical Research: Earth Surface. 112(F3).

Larsen IJ, Montgommery DR, Korup O (2010) Landslide erosion controlled by hillslope material. Nature Geoscience. 3(4): 247-251.

Ouimet WB, Whipple KX, Royden LH, Sun Z, Chen Z (2007) The influence of large landslides on river incision in a transient landscape: Eastern margin of the Tibetan Plateau (Sichuan, China). Geological Society of America Bulletin. 119(11-12): 1462-1467.

Ross L, de Swart H, Ensing E, Valle-Levinson A (2017) Threedimensional tidal flow in a fjord-like basin with converging width: An analytical model. Journal of Geophysical Research: Oceans. 122(9): 7558-7576.

Saintot A, Dahle H, Derron M-H, Henderson I, Oppikofer T (2012) Large gravitational rock slope deformation in Romsdalen valley (Western Norway). Revista de la Asociación Geológica Argentina 69: 354-371.

Stroeven, AP, Hättestrand C, Kleman J, Heyman J, Fabel D, Fredin O, Goodfellow BW, Harbor JM, Jansen JD, Olsen L, Caffee MW, Fink D, Lundqvist J, Rosqvist GC, Strömberg B, Jansson KN (2016) Deglaciation of Fennoscandia. Quaternary Science Reviews 147: 91-121.

Svendsen JI and Mangerud J (1987) Late Weichselian and Holocenesea-level history for a cross-section of western Norway. Journal of Quaternary Science 2: 113-132.

Winsemann J, Hornung JJ, Meinsen J, Asprion U, Polom U, Brandes C, Bußmann M, Weber C (2009) Anatomy of a subaqueous ice-contact fan and delta complex, Middle Pleistocene, North-west Germany. Sedimentology. 56(4): 1041-1076.

(1) Paula Hilger $(\square)$

Western Norway University of Applied Sciences, Department for Environmental Sciences, 6851 Sogndal, Norway

e-mail: paula.hilger@hvl.no

(2) Reginald L. Hermanns

Geological Survey of Norway, Geohazards and Earth observation, 7040 Trondheim, Norway

Norwegian University of Science and Technology, Department of Geoscience and Petroleum, 7491 Trondheim

e-mail: reginald.hermanns@ngu.no

(3) Bernd Etzelmüller

University of Oslo, Department of Geosciences, 0371 Oslo, Norway

e-mail: bernd.etzelmuller@geo.uio.no 